\title{
Detection of Hepatitis B Surface Antigen among Scottish Blood Donors: Evaluation of Sensitive Tanned-cell Haemagglutination-inhibition Test
}

\author{
R. HOPKINS, M. ROBERTSON, D. ROSS, W. M. TURNBULL, P. C. DAS
}

British Medical fournal, 1975, 2, 409-411

\begin{abstract}
Summary
A total of 70224 blood donations were tested at three Scottish blood transfusion centres for hepatitis B surface antigen (HBsAg) by an economical haemagglutinationinhibition method (E.H.A.I.) and the results compared with those of counterelectrophoresis (C.E.P.). A further 4086 donations were tested using the Wellcome turkey cell haemagglutination test, C.E.P., and E.H.A.I. E.H.A.I. was also compared with commercial haemagglutination and radioimmunoassay reagents for sensitivity and specificity against several established antigen panels and used to reinvestigate counterelectrophoresis-negative blood donations implicated in post-transfusion hepatitis.

E.H.A.I. combines the inherent specificity of an inhibition reaction with a sensitivity.equal to that of commercial radioimmunoassay and haemagglutination kits but at a fraction of the cost. The assessment of 70224 blood donations in three regions showed that E.H.A.I. detected more antigen-positive blood donations than C.E.P. Results of retesting more than 100 blood donors implicated in 10 cases of post-transfusion hepatitis suggested that the use of E.H.A.I. or a test of similar sensitivity in place of C.E.P. may significantly reduce the incidence of this complication.
\end{abstract}

Regional Transfusion Centre, Royal Infirmary, Edinburgh EH3 9HB R. HOPKINS, B.SC., Scientific Officer

M. ROBERTSON, F.I.M.L.T., Senior Technician

P. C. DAS, M.B., PH.D., Medical Assistant

Regional Transfusion Centre, Raigmore Hospital, Inverness D. ROSS, F.I.M.L.T., Senior Technician

Regional Transfusion Centre, Royal Infirmary, Dundee W. M. TURNBULL, F.I.M.L.T., Chief Technician

\section{Introduction}

Despite the identification of the causal agent of type B posttransfusion (serum) hepatitis, ${ }^{1}$ and the subsequent removal of blood identified as positive for $\mathrm{HBsAg}$ by counterelectrophoresis (C.E.P.) hepatitis continues to complicate the therapeutic use of blood and blood products. ${ }^{2}$ More sensitive serological tests for surface antigen might lead to a reduction in the number of cases of post-transfusion hepatitis but are unlikely to eliminate it completely because of the potential infectivity of blood containing antibody to the Dane particle core $^{3}$ and the possible existence of a reputed hepatitis $C$ virus ${ }^{4}$ -quite apart from other causes such as hepatitis virus $A$ (infectious hepatitis) and other microbial agents. ${ }^{5}$

The relatively insensitive technique of C.E.P. ${ }^{6}$ is most commonly used in blood banks. Much more sensitive assays, using principles of haemagglutination or radioimmunoassay, are now commercially available. ${ }^{7-10}$ Some reports suggest that these kits can detect carriers of $\mathrm{HBsAg}$ too weak to be positive on C.E.P. ${ }^{7-9}$ Unfortunately, their effective use in the blood transfusion service will prove expensive and only time will tell whether such expense is justified.

We report here the experience of three Scottish blood transfusion centres in evaluating a sensitive and economical tannedcell haemagglutination-inhibition test (E.H.A.I.). ${ }^{11}$ In addition to a field assessment involving 70224 blood donations the test was compared with commercial haemagglutination and radioimmunoassay kits for specificity and sensitivity. We also present data on the retesting of 138 blood donors' sera which were HBsAg negative on initial screening by C.E.P. but were later implicated in post-transfusion hepatitis in 10 patients.

\footnotetext{
Methods

Haemagglutination Inhibition.-The test used was the "mini-micro" version of that described by Hopkins and Das"11 in which washed, $\beta$-propiolactone/ultra-violet light-treated antigen was used to sensitize human $O R$ h-negative erythrocytes. Test serum was diluted $1 / 10$ or $1 / 5$ in phosphate-buffered saline and the test conducted in Terasaki trays using only $5 \mu \mathrm{l}$ of reagent. Antibody was detected by
} 
direct haemagglutination. Sera positive for $\mathrm{HBsAg}$ were confirmed by subtyping (ad/ay) using a modification of the test assay. ${ }^{12}$

Other Assays. - C.E.P. was performed as previously described, ${ }^{6}$ and the plates were washed with $1 \%$ tannic acid before reading. Radioimmunoassay (Ausria, Abbott Laboratories) and haemagglutination (Auscel, Abbott Laboratories; Hepanosticon, Organon; and turkey cells; Wellcome Reagents) were performed as recommended by the manufacturers.

Blood Donor Testing.-Three Scottish regional transfusion centres have been evaluating E.H.A.I. for large-scale donor testing: the North of Scotland Blood Transfusion Centre have tested 16371 donations by E.H.A.I. and C.E.P. since August 1973; the Edinburgh and South-East of Scotland Blood Transfusion Centre have tested 44053 donations since February 1974; 4086 of which were also tested with the turkey-cell reagent; the East of Scotland Blood Transfusion Centre have tested 9800 donations by E.H.A.I. Antigen suitable for cell sensitization was prepared centrally at Edinburgh, but cell sensitization and subsequent standardization were performed at each centre independently.

Panel Studies.-In addition to sera from the N.I.H. panel (no. 2), which we have studied before, 12 the following antigen panels were investigated: (a) Public Health Laboratory panel (A) supplied by the Standards Laboratory for Serological Reagents and consisting of 25 antigen-positive sera of varying concentrations; (b) Canadian Red Cross panel containing weakly antigen-positive sera (and one antibody specimen)-this has recently been used in a multicentre C.E.P. study $;^{13}$ (c) American Red Cross panels (1) containing antigen-

TABLE I-Incidence of HBsAg Among Blood Donors Tested at Three Centres

\begin{tabular}{|c|c|c|c|c|c|}
\hline & & & $\begin{array}{l}\text { No. Donations } \\
\text { Tested }\end{array}$ & $\begin{array}{l}\text { No. Positive } \\
\text { on E.H.A.I. }\end{array}$ & $\begin{array}{l}\text { No. Positive } \\
\text { on C.E.P. }\end{array}$ \\
\hline $\begin{array}{l}\text { Edinburgh } \\
\text { Inverness } \\
\text { Dundee .. }\end{array}$ & $\begin{array}{l}\ldots \\
\ldots\end{array}$ & $\begin{array}{l}\ldots \\
\therefore \\
\therefore\end{array}$ & $\begin{array}{r}44053 \\
16371 \\
9800\end{array}$ & $\begin{array}{r}18 \\
4 \\
4\end{array}$ & $\begin{array}{r}14 \\
2 \\
3\end{array}$ \\
\hline Total & $\ldots$ & $\ldots$ & 70224 & 26 & 19 \\
\hline
\end{tabular}

positive material of varying concentration, negative controls, and sera which gave false-positive reactions by radioimmunoassay when originally tested in the U.S.A., (2) containing 26 antigen-positive coded sera of different subtypes.

Comparative Titration Sensitivity.-Seven techniques were used to assess relative sensitivity against a standard $a d$ antigen and a standard ay antigen.

Post-transfusion Hepatitis.-Since mid-1973 the South-East region has stored $0.5-\mathrm{ml}$ aliquots of serum at $-20^{\circ} \mathrm{C}$ from all donations, so we were able to retest the original donations given to eight patients referred with suspected post-transfusion hepatitis by R.I.A., E.H.A.I., and C.E.P. E.H.A.I. was also used to assay two similar specimens supplied by Manchester Regional Blood Transfusion Centre. These sera were obtained at a return visit of the donors and were therefore not truly representative of the original donation. They had all been retested by C.E.P. and electron microscopy and found to be antigen negative before their arrival in our laboratory.

\section{Results and Comments}

E.H.A.I. detected seven HBsAg-positive carriers (two previously implicated in post-transfusion hepatitis and five donating blood for the first time) which were missed by counterelectrophoresis (table I), each centre finding at least one additional positive. E.H.A.I. compares well in sensitivity to commercial haemagglutination and radioimmunoassay kits (table II), a finding borne out by the results obtained from the antigen panels studied (table III). All antigen-positive sera were correctly identified by E.H.A.I. with no non-specific reactions. Hepanosticon, however, missed two positive sera and the turkey cells failed to detect the weakest antigen-positive sample in the American Red Cross panel (1). Auscel gave three false-positive reactions in the American Red Cross panel (1). During the screening of 4086 blood donations with the turkey cells, C.E.P., and E.H.A.I. each method detected the three positive sera, but there were 20 false-positive reactions with turkey cells.

The retesting of more than 100 donations implicated in eight cases of post-transfusion hepatitis in Edinburgh (cases 1-8, table IV; five

TABLE II-Comparison of Titration Sensitivity of Haemagglutination Tests, C.E.P., and R.I.A. for HBsAg. Results are Reciprocals of Maximum Titres Recorded

\begin{tabular}{|c|c|c|c|c|c|c|c|c|c|c|}
\hline & & & C.E.P. & Hepanosticon & Turkey Cells & Auscell & E.H.A.I.* & E.H.A.I. $\dagger$ & Ausria I & Ausria II \\
\hline $\begin{array}{l}\text { ad } \\
\text { ay }\end{array}$ & $\therefore$ & $\therefore$ & $\begin{array}{r}2 \\
16\end{array}$ & $\begin{array}{l}400 \\
800\end{array}$ & $\begin{array}{l}1000 \\
4000\end{array}$ & $\begin{array}{l}64000 \\
32000\end{array}$ & $\begin{array}{l}2000 \\
8000\end{array}$ & $\begin{array}{l}32000 \\
64000\end{array}$ & $\begin{array}{r}16000 \\
2000\end{array}$ & $\begin{array}{l}8000 \\
4000\end{array}$ \\
\hline
\end{tabular}

* With four units of antibody for inhibition.

* With four units of antibody for inhibition.
+ With three units of immune absorbed high affinity antibody for inhibition.

TABLE III-Results of Antigen Panel Studies

\begin{tabular}{|c|c|c|c|c|c|c|c|c|c|c|}
\hline & & \multirow{2}{*}{\multicolumn{2}{|c|}{ Public Health Laboratory Panel }} & \multirow{2}{*}{\multicolumn{2}{|c|}{ Canadian Red Cross Panel* }} & \multicolumn{5}{|c|}{ American Red Cross Panel } \\
\hline & & & & & & \multicolumn{3}{|c|}{ (1) } & \multicolumn{2}{|c|}{ (2) } \\
\hline & & Positive & Negative & Positive & Negative & True Positive & False Positive & False Negative & Positive & Negative \\
\hline $\begin{array}{l}\text { C.E.P. } \\
\text { Turkey cells } \\
\text { Ausria I } \quad \cdots \\
\text { U.S.A. } \quad \cdots \\
\text { U.K. } \\
\text { Hepanosticon } \\
\text { Auscell } \quad \cdots \\
\text { E.H.A.I. } \quad \cdots\end{array}$ & $\begin{array}{l}. \\
\because \\
\because \\
\because \\
\cdots \\
\therefore\end{array}$ & $\begin{array}{l}20 \\
25 \\
25 \\
\\
23 \\
25\end{array}$ & $\begin{array}{l}5 \\
0 \\
0 \\
2 \\
0\end{array}$ & 3 & 6 & $\begin{array}{r}6 \\
9 \\
10 \\
10 \\
10 \\
10\end{array}$ & $\begin{array}{l}0 \\
0 \\
9 \\
0 \\
3 \\
0\end{array}$ & $\begin{array}{l}4 \\
1 \\
0 \\
0 \\
0 \\
0\end{array}$ & 23 & 3 \\
\hline
\end{tabular}

* This panel also contained another specimen with antibody (anti-HBsAg).
† 13 ad, 13 ay.

TABLE IV-Results of Reinvestigation of Donors implicated in 10 Cases of Post-transfusion Hepatitis. All Donations were Originally Found to be Negative by C.E.P.

\begin{tabular}{|c|c|c|c|c|c|c|c|c|c|c|}
\hline Case no.: & 1 & 2 & 3 & 4 & 5 & 6 & 7 & 8 & 9 & 10 \\
\hline $\begin{array}{l}\text { HBsAg } \\
\text { No. of donations involved } \\
\text { No. of donations found to } \\
\text { be positive and method.. }\end{array}$ & + & $\stackrel{+}{14}$ & $\begin{array}{c}\overline{18} \\
1 \text { by A.I., } \\
\text { E.H.A.I., } \\
\text { and T.C. }\end{array}$ & $\stackrel{+}{18}$ & $\stackrel{+}{32}$ & $\begin{array}{c}+\stackrel{+}{14} \\
1 \text { by A.I., } \\
\text { E.H.A.I., } \\
\text { and T.C. }\end{array}$ & $\overline{3}$ & $\overline{10}$ & $\begin{array}{l}+ \\
4 \\
1 \text { by A.I., } \\
\text { and } \\
\text { E.H.A.I. }\end{array}$ & $\begin{array}{l}\text { N.T. } \\
17 \\
1 \text { by } \\
\text { E.H.A.I. } \\
\text { and T.C. }\end{array}$ \\
\hline
\end{tabular}

A.I. = Ausria I. E.H.A.I. = Economical haemagglutination inhibition. T.C. $=$ Turkey cells. N.T. $=$ Not tested. 
patients were antigen positive) showed that in two cases an antigenpositive unit of blood had been transfused which was undetectable by the electrophoresis method during the initial screening as well as on reinvestigation. In both cases antigen was detected only by the more sensitive tests (table IV). On reinvestigation of the two cases from Manchester (cases 9 and 10) a positive unit was detected in both cases, though one was missed by turkey cells and the other by Ausria $I$. The antigen-positive unit transfused in case 9 was subtyped as ad, while that transfused in case 10 was found to be $a y$, confirming the finding of the titration study (table II) in which Ausria I showed a bias towards detection of the ad subtype, despite that all other tests except Auscel found ad to be weaker. A similar bias in favour of the ad subtype was recorded by Vanderweld et al., ${ }^{14}$ but this fault seems to have been corrected to some extent in the newer Ausria II test (table II).

\section{Discussion}

Recent reports have highlighted the inadequacies of C.E.P. in detecting HBsAg in blood donations. ${ }^{2}{ }^{7-10}$ The American Red Cross seem to have opted for R.I.A., while regional transfusion centres in the U.K. seem to favour haemagglutination. Three commercial haemagglutination assays, all using agglutination of antibody-coated erythrocytes, are currently available. The cheapest of these (about 10p per test if ordered in bulk) is marketed by Wellcome Reagents, and consists of fixed turkey erythrocytes coated with affinity column purified antibody raised in horses. In terms of speed and simplicity it is well suited to the largescale testing of blood donations, ${ }^{1015}$ and its sensitivity is much greater than that of C.E.P. but less than that of R.I.A. The other two haemagglutination tests-Hepanosticon, which consists of fixed sheep erythrocytes coated with antibody raised in sheep, and Auscel, which consists of fixed human erythrocytes coated with antibody raised in guinea pigs-have been found to be more sensitive than C.E.P. ${ }^{8}{ }^{9}$ All three tests are susceptible to a few false-positive reactions, the problem being solved by absorption-titration experiments.

Our E.H.A.I. test is about as sensitive as R.I.A. and, being an inhibition reaction, has an inherent specificity not found in the haemagglutination tests. The use of monospecific antibody (prepared by absorption or affinity chromatography) allows E.H.A.I. to be used to subtype antigen-positive sera, which provides an essential confirmatory step. ${ }^{12}$

The cost of E.H.A.I. is negligible owing to the availability of raw material, the considerable expertise in haemagglutination technology within the Blood Transfusion Service, and the simplicity of reagent preparation combined with the small quantities $(5 \mu \mathrm{l})$ needed for testing. In one week $500 \mathrm{ml}$ of high-titre $\mathrm{HBsAg}$-positive serum was processed to provide enough antigen for the sensitization of sufficient cells to test 720000 donations for both antigen and antibody. We estimate that about 40 tests can be done for $1 \mathrm{p}$.

The prime criterion in evaluating a new screening test must be the number of additional antigen carriers detected in comparison with current techniques. Our results indicate that E.H.A.I. detects several donations possessing $\mathrm{HBsAg}$ in concentrations below the sensitivity of C.E.P. The importance of these findings is emphasized by the results obtained from the retesting of blood donations implicated in post-transfusion hepatitis, which serves as a measure of the efficiency of $\mathrm{HBsAg}$ testing within the Blood Transfusion Service. On the three occasions in which a C.E.P. false-negative donation was detected by R.I.A. it was also detected by E.H.A.I.; furthermore, E.H.A.I. detected one out of 17 units transfused which remained R.I.A. negative (table IV). This tends to confirm the findings of Koretz et al., ${ }^{16}$ who reported that a positive haemagglutination reaction was more closely related with hepatitis or seroconversion than was a positive R.I.A. reaction.

E.H.A.I. may prove acceptable in large-scale blood donor testing. The incidence of antibody, detected by direct haemagglutination, is about $10-20$ times greater than that detected by C.E.P. (252/31 999 v. 13/31 999), thus not only providing valuable materials for laboratory reagents but also increasing the quantity of antibody for subsequent fractionation of hepatitis $B$ immunoglobulin for therapeutic use. It seems that with appropriate training the technique may be readily introduced into any regional transfusion centre, thereby keeping reagent costs to a minimum. The basic technology has been adapted to a rapid microcapillary test for use in emergencies ${ }^{17}$ and is being automated in Inverness and modified for the detection of antibody to the Dane particle core in Edinburgh.

We thank Dr. J. D. Cash, Dr. I. A. Cook, and Dr. C. Cameron, regional directors of the South-East, North, and East regions respectively, for continued support and encouragement during this project. We also thank Mr. R. Y. Dodd and Dr. T. J. Greenwalt (American National Red Cross), Dr. B. P. L. Moore (Canadian Red Cross Society), and Dr. P. Bradstreet (Public Health Laboratory Service) for kindly providing the antigen panels. We are grateful to Dr. L. D. Wadsworth (Manchester Blood Transfusion Service) for allowing us to report on two cases of post-transfusion hepatitis. Finally, we thank Abbott Laboratories for the timely arrival of an Ausria II evaluation kit.

\section{References}

1 Giles, J. P., et al., New England Fournal of Medicine, 1969, 281, 119 2 Reinicke, V., Banke, O., and Dybkjaer, E., Vox Sanguinis, Suppl., 1973, 24,65 .

${ }^{3}$ Hoofnagle, J. H., et al., New England fournal of Medicine, 1974, 290, 1336.

3 Hoofnagle, J. H., et al., New England fournal
4 Prince, A. M., et al., Lancet, 1974, 2, 241.

5 Zuckerman, A. J., Virus Diseases of the Liver, London, Butterworths, 1970

6 Hopkins, R., and Das, P. C., Fournal of Clinical Pathology, 1972, 25, 832.

Ling, C. M., and Overby, L. R., Fournal of Immunology, 1972, 109, 834. Germain, K. H., Sturdivant, S. K., and Rightsel, W. A., Applied Microbiology, 1973, 25, 524 .

' Reesink, H. W., Duimel, W. J., and Brummelhuis, H. G. J., Lancet, $1973,2,1351$.

10 Cayzer, I., et al., Lancet, 1974, 1, 947.

11 Hopkins, R., and Das, P. C., fournal of Haematology, 1973, 25, 619.

12 Hopkins, R., and Das, P. C., British fournal of Haematology, 1974, 27, 501 .

13 Moore, B. P. L., et al., Vox Sanguinis, 1974, 26, 128.

14 Vandervelde, E. M., et al., Lancet, 1974, 2, 1066.

15 Chrystie, I. L., et al., Lancet, 1974, 1, 1193.

16 Koretz, et al., Lancet, 1973, 2, 694.

17 Leslie, M., Hopkins, R., and Das, P. C., Medical Laboratory Technology, in press. 